\title{
Magnets for MUON 6D Helical Cooling Channels
}

\section{Cooperative Research and Development Agreement Final Report}

CRADA Number: FRA-2007-0002

\section{Fermilab Technical Contact: Alexander Zlobin}

Summary Report

24 May 2011 


\section{NOTICE}

This report was prepared as an account of work sponsored by an agency of the United States government. Neither the United States government nor any agency thereof, nor any of their employees, makes any warranty, express or implied, or assumes any legal liability or responsibility for the accuracy, completeness, or usefulness of any information, apparatus, product, or process disclosed, or represents that its use would not infringe privately owned rights. Reference herein to any specific commercial product, process, or service by trade name, trademark, manufacturer, or otherwise does not necessarily constitute or imply its endorsement, recommendation, or favoring by the United States government or any agency thereof. The views and opinions of authors expressed herein do not necessarily state or reflect those of the United States government or any agency thereof.

Available electronically at http://www.osti.gov/bridge

Available for a processing fee to U.S. Department of Energy and its contractors, in paper, from:

U.S. Department of Energy Office of Scientific and Technical Information

P.O. Box 62

Oak Ridge, TN 37831-0062

phone: 865.576 .8401

fax: 865.576 .5728

email: mailto:reports@adonis.osti.gov

Available for sale to the public, in paper, from:

U.S. Department of Commerce

National Technical Information Service

5285 Port Royal Road

Springfield, VA 22161

phone: 800.553 .6847

fax: 703.605.6900

email: orders@ntis.fedworld.gov

online ordering: http://www.ntis.gov/ordering.htm 
In accordance with Requirements set forth in Article XI.A(3) of the CRADA document, this document is the final CRADA report, including a list of Subject Inventions, to be forwarded to the Office of Science and Technical Information as part of the commitment to the public to demonstrate results of federally funded research.

CRADA number: $\quad$ FRA-2007-0002

CRADA Title: $\quad$ Magnets for MUON 6D Helical Cooling Channels

Parties to the Agreement: $\quad$ MUONS, Inc and Fermi Research Alliance, LLC

\section{Abstract of CRADA work:}

MANX is a 6-dimensional muon ionization-cooling experiment that has been proposed to Fermilab to demonstrate the use of a Helical Cooling Channel (HCC) for future muon colliders and neutrino factories. The HCC for MANX has solenoidal, helical dipole, and helical quadrupole magnetic components which diminish as the beam loses energy as it slows down in a liquid helium absorber inside the magnets. Additional magnets that provide emittance matching between the HCC and upstream and downstream spectrometers are also described as are the results of G4Beamline simulations of the beam cooling behavior of the complete magnet and absorber system.

Muons, Inc is proposing to develop designs and construction methods for these magnets and to design a complete magnet system for a six-dimensional muon beam cooling channel. The scope of this CRADA is limited to the baseline conceptual design and planning for a proposed Phase II project. Funded in part by STTR grant DE-FG02-06ER86282.

\section{Summary of Research Results:}

The MANX demonstration experiment should be based on the Helical Solenoid magnet system.

- The Helical Solenoid generates the longitudinal and transverse helical magnetic fields for effective ionization-cooling.

- The magnetic and mechanical analyses of the Helical Solenoid have confirmed that the magnet system can be built.

- The Helical Solenoid could be combined with a helical RF cavity to compensate muon energy loss in the absorber. 


\section{Related Reports, Publications, and Presentations:}

Muons, Inc. Final Technical Report on STTR Project DE-FG02-06ER86282 Development and Demonstration of 6-Dimensional Muon Beam Cooling. United States: N. p., 2011.Web. doi:10.2172/1015012. (OSTI Identifier: 1015012)

PAC07, Albuquerque, NM, June 2007, IEEE, APS, LANL, “Magnets for the MANX 6-D Muon Cooling Demonstration Experiment" (MOPAS012)

EPAC08, Genoa, Italy, June 2008, EPS-AG, IEEE, APS, “Magnets for the MANX 6-D Muon Cooling Demonstration Experiment"

\section{Subject Inventions listing:}

None

Report Date: 24 May 2011

Technical Contact at Fermilab: Alexander Zlobin

This document contains NO confidential, protectable or proprietary information. 